\title{
Is the lower Hudson-Raritan estuary a suitable habitat for Gonyaulax tamarensis?
}

\author{
J. B. Mahoney, D. Hollomon, R. Waldhauer \\ U. S. Department of Commerce, National Oceanic and Atmospheric Administration, National Marine Fisheries Service, \\ Northeast Fisheries Center, Sandy Hook Laboratory, Highlands, New Jersey 07732 , USA
}

\begin{abstract}
The toxic dinoflagellate Gonyaulax tamarensis Lebour [= Protogonyaulax tamarensis (Lebour emend. Taylor) Taylor = Alexandrium tamarense (Lebour) Balech) has not been identified in the lower Hudson-Raritan estuary, a characteristically hypertrophic, contaminated system but is widespread and sometimes abundant in nearby Long Island, New York waters. Our hypothesis is that anthropogenic contaminants can be important regulators of $G$. tamarensis in the Hudson-Raritan estuary. To address this, we conducted a series of bioassays of water collected from 2 locales in Lower New York Bay during July through September, the usual period of flagellate maxima. In the assays, $G$. tamarensis growth regulation by nitrogen, phosphorus and vitamins was relatively unimportant, less important than that of one or more components of a metals mix. Nitrogen had a primary limiting role or shared primary importance with other enrichments in just 7 and $18 \%$ of the assays, respectively; phosphorus and vitamins were less limiting. Growth inhibition in the assays, which could be relieved by chelation and/or treatment of the water with activated carbon, was prevalent. Assuming the persistence of similar chemical water quality in Lower New York Bay, the results suggest that, although nutrient limitation of G. tamarensis would be improbable, this habitat would not be generally favorable. However, because the dinoflagellate grew relatively well in the unenriched, untreated bay water in $20 \%$ of the assays, and at least survived in most of the remainder, the chemical water quality does not appear to exclude it. We conclude that $G$. tamarensis is unlikely to become a principal resident phytoplankter in the bay, assuming its introduction, but it may be able to establish itself temporarily when water quality is favorable for the species.
\end{abstract}

\section{INTRODUCTION}

The detection of cysts of the toxic dinoflagellate Gonyaulax tamarensis Lebour $[=$ Protogonyaulax tamarensis (Lebour emend. Taylor) Taylor = Alexandrium tamarense (Lebour) Balech] in southern New England and Long Island, New York (Anderson et al. 1982) drew attention to the presence of the species in these areas. Subsequently, Freudenthal (pers. comm.) found planktonic cells and benthic cysts of the species in numerous locales in western Long Island; Schrey et al. (1984) identified planktonic cells, in abundances generally below 10000 cells $1^{-1}$ but ranging to 200000 cell $\mathrm{l}^{-1}$, at 46 of 115 estuarine sites in eastern Long Island. Associated paralytic shellfish poison (PSP), however, has not been a major problem south of Massachusetts although Anderson et al. (1982) cited a 1979 occurrence in Narragansett Bay, Rhode Island, and the first documented episode in Connecticut was detected at Groton in 1985 (Blogoslawski pers. comm.). Several $G$. tamarensis isolates from different Long
Island locales are toxic (Maranda et al. 1985) and PSP was detected in Flanders Bay, Long Island shellfish in May 1986 (Nuzzi pers. comm.). It appears reasonable, therefore, to assume that PSP may become a threat in New York and New Jersey if the dinoflagellate flourishes in local waters.

We ask: 'Is the lower Hudson-Raritan estuary a suitable habitat for Gonyaulax tamarensis?' Hypertrophic Lower New York Bay and adjacent waters have almost annual intense phytoflagellate blooms; cell concentrations of Olisthodiscus luteus, for example, commonly reach 3 to $4 \times 10^{8}$ cells $1^{-1}$ (Mahoney \& McLaughlin 1977). O'Reilly et al. (1976) found that the primary productivity at a station in Lower New York Bay was higher than in all other marine environments where phytoplankton are the main producers. A major G. tamarensis red tide in the Hudson-Raritan estuary could cause serious effects in this ecosystem and possibly seed prime New Jersey shellfish areas to the south. However, despite its recent high incidence in nearby Long Island, the species was not identified in 
phytoplankton monitoring in New York Harbor and adjacent New Jersey waters by this laboratory in the past $20 \mathrm{yr}$, nor in joint intense phytoplankton surveys in these waters with the New Jersey Department of Environmental Protection over the last decade (Olsen \& Cohn 1979, Olsen 1983). G. tamarensis has been

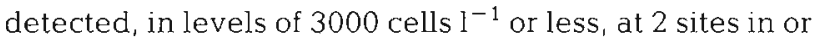
near Atlantic City in the southern part of New Jersey (Cohn et al. 1988). Marshall \& Cohn (1981) found low concentrations of the species ( 8 to 24 cells l$^{-1}$ ) at several sites along the New Jersey coast, as close as $10.0 \mathrm{~km}$ from shore.

Our hypothesis to account for the lack of success and apparently even absence of Gonyaulax tamarensis in the Hudson-Raritan estuary is that the ambient chemical water quality is unfavorable for the species. The Lower New York Bay system has been long considered seriously polluted with sewage and industrial wastes (Federal Water Pollution Control Administration 1967). A recent evaluation of chemical pollution in the Hudson-Raritan estuary concluded that some metals, including mercury, copper, lead and cadmium (Breteler et al. 1984), certain petroleum hydrocarbons (Neff 1984), and certain halogenated hydrocarbons (Zitko \& Boehm 1984) are at levels threatening to the biota and human health. Waldhauer et al. (1978) determined copper maxima (to $65 \mathrm{ppb}$ ) in Lower New York Bay to be the highest documented for estuarine waters. Due to reduced river flow, metal levels in New York Harbor and adjacent ocean waters are highest in the summer (Segar \& Cantillo 1976), the usual time of flagellate maxima in the region. G. tamarensis has relatively high sensitivity to copper (Anderson \& Morel 1978, Schenck 1984). The effects of organic contaminants on $G$. tamarensis have not been determined, or at least not reported, but it is known (e.g. Fisher et al. 1974, Biggs et al. 1978) that several organochlorines such as PCB are toxic to marine phytoplankton. The Hudson-Raritan estuary is one of the estuaries most contaminated with PCB in the country (Zdanowicz et al. 1986).

Another explanation for the species absence in the Hudson-Raritan estuary is simply that it has not reached there yet. Anderson et al. (1982) mentioned the possibility of a continuing southward movement of the dinoflagellate from the Gulf of Maine since 1972. This suggests eventual migration into the estuary and if this occurs, the subsequent success of Gonyaulax tamarensis in these waters is in question. In a $3 \mathrm{yr}$ phytoplankton survey (1974-1976), Olsen \& Cohn (1979) found various Gonyaulax spp. including $G$. apiculata, $G$. diacantha, $G$. diegensis, G. longicornu, $G$. polyedra, G. scrippsae and $G$. spinifera in Lower New York Bay and adjacent waters, but never in abundance. However, a Gonyaulax red tide in these waters is a possibility since an intense bloom of G. scrippsae took place in 1963 throughout the southern half of Lower New York Bay (Prager et al. 1963). To gauge the potential success of $G$. tamarensis in the bay, this study has examined the suitability of the water for this species in a July through September period.

\section{MATERIALS AND METHODS}

Hydrography and seasonal change of nutrient concentrations in the Hudson-Raritan estuary over a spring-to-fall period are discussed in Draxler et al. (1984). The hydrography of the lower estuary is dominated by the flow of the Hudson River (average $540 \mathrm{~m}^{3}$ $\mathrm{s}^{-1}$ ) and the Raritan River (average $24 \mathrm{~m}^{3} \mathrm{~s}^{-1}$ ) (Mueller et al. 1976) and tidal mixing. In 1982, when we began this study, the flow of the Hudson River (U. S. Geological Survey 1983a) and Raritan River (U. S. Geological Survey 1983b) peaked in April and decreased to the low levels for the year in July through September. In the latter months, Hudson River flow (at Green Island, NY) was decreased to 11 to $17 \%$ of maximum and Raritan River flow (at Manville, NJ) was 22 to $29 \%$ of maximum.

Two stations in Lower New York Bay (Fig. 1) were sampled, $0.5 \mathrm{~m}$ from surface and bottom, on 7 occasions in July through September 1982. Bottom sampling depth varied with tide but averaged 5.5 and $9.5 \mathrm{~m}$ for Stations 7 and 13, respectively. The stations were chosen from those established by the U.S. Environmental Protection Agency, Raritan Bay Project.

Liter water samples for assay and chemical analyses were collected in duplicate with a Niskin bottle. Within approximately $3 \mathrm{~h}$ of collection the assay samples were filtered with $1.0 \mu \mathrm{m}$ porosity Millipore (EA type) membranes and freezer-stored. Aliquots of the water for chemical analyses were pressure filtered $(<0.07 \mathrm{~atm})$ through Whatman GF/F glass fiber filters (nominal pore size $0.7 \mu \mathrm{m}$ ) into borosilicate vials for ammonium determinations and into polyethylene vials for nitrite. nitrate and reactive phosphorus determinations. After phenol/alcohol addition to the ammonium vials, all subsamples were frozen until analysis. Analytical methods were those of Liddicoat et al. (1975) for ammonium, Wood et al. (1964) for nitrite and nitrate, and Murphy \& Reilly (1962) for reactive phosphorus.

All sample storage bottles and vials were cleaned with $10 \% \mathrm{HCl}$ for $12 \mathrm{~h}$ and rinsed with deionizeddistilled water Before use, the membrane filters were flushed with $200 \mathrm{ml}$ of deionized-distilled water; analyses of filtrate after washing showed that type EA membranes contributed negligible amounts of nitrogen and phosphorus. Whatman GF/F filters for chemistry aliquots were flushed with a portion of the same bay water sample being filtered. For the assays, culture 
Fig. 1. Sampling locations in Lower New York Bay

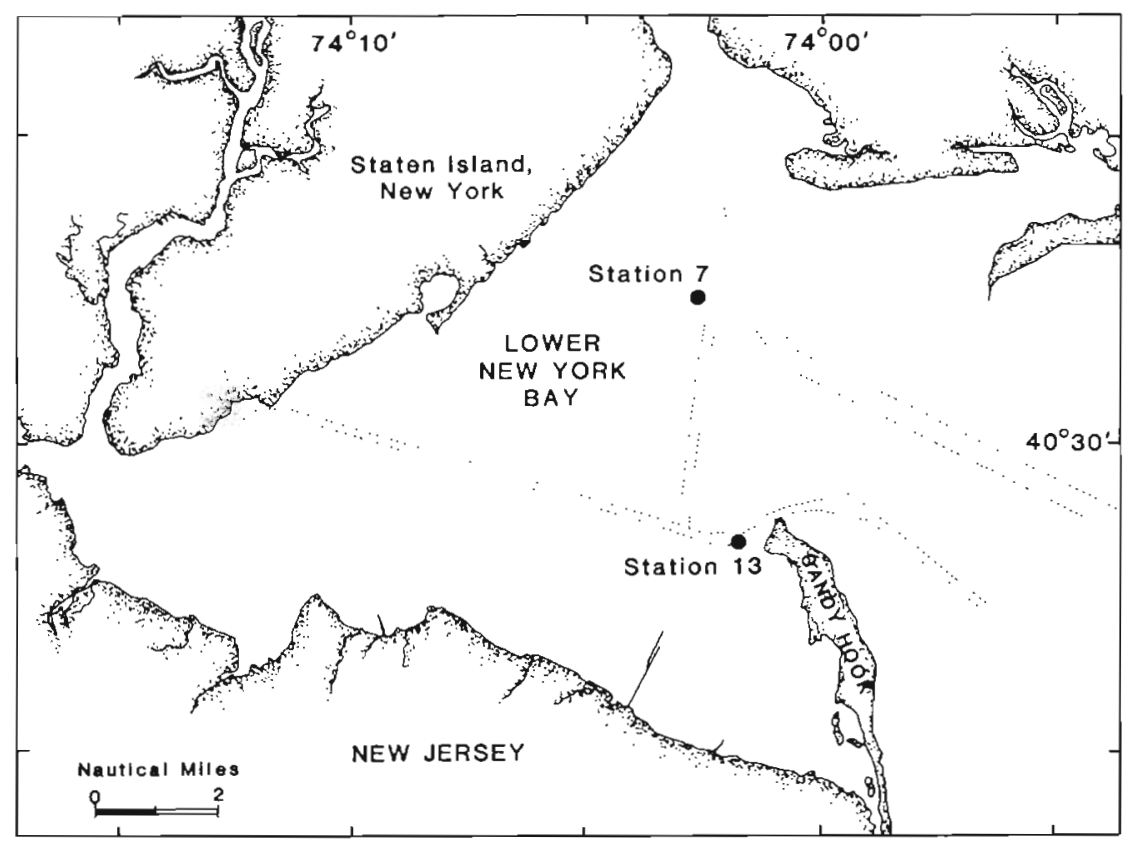

tubes and experiment glassware cleaning included a soak in Micro detergent, tap water rinse, soak in $10 \%$ $\mathrm{HCl}$, and machine wash with final deionized-distilled water rinse. Prosil-28 treatment of the assay glassware (Erickson pers. comm.) provided a silicone coating to increase chemical resistivity.

The assay enrichments (reagent grade chemicals) and EDTA, activated carbon (Norit A) treatments are shown in Table 1 . The method for preparing activated carbon was that of Carlucci (1973) with the addition of a final rinse with deionized-distilled water. Following the enrichments and treatments to sample aliquots, the $\mathrm{pH}$ was adjusted to 8.0 with $\mathrm{NaOH}$ or $\mathrm{HCl}$. The assay water was then dispensed in $15 \mathrm{ml}$ aliquots into $20 \times$ 150 borosilicate tubes having teflon-lined caps. Sterilization was by mild autoclaving $\left(12 \mathrm{lbs}, 102\right.$ to $105^{\circ} \mathrm{C}$ for $10 \mathrm{~min}$ ) in an autoclave supplied with deionized water. No precipitate was seen in the tubes after autoclaving.

Table 1. Enrichments and water treatments

A. No supplementation

B. $\mathrm{NaNO}_{3}, 50.0 \mu \mathrm{g}$-at $\mathrm{N}^{-1}$

C. $\mathrm{NaH}_{2} \mathrm{PO}_{4}, 5.0 \mu \mathrm{g}$-at $\mathrm{Pl}^{-1}$

D. Vitamins mix $\left(\mu \mathrm{g} \mathrm{l}^{-1}\right), \mathrm{B}_{12}, 0.5$; biotin, 0.5 ; thiamine, 100.0

E. Metals mix $\left(\mu \mathrm{gl}^{-1}\right), \mathrm{Fe}, 50.0 ; \mathrm{Zn}_{\mathrm{n}}, 5.0 ; \mathrm{CO}, 2.5 ; \mathrm{Mn}, 50.0$; Mo, 2.5

F. EDTA, $4.45 \mathrm{mg} \mathrm{l}^{-1}$

G. Treatment E plus $F$

H. Treatment $B, C, D$, and $E$

I. Treatment $\mathrm{H}$ plus $\mathrm{F}$

J. Activated carbon treatment, then $H$ supplements

K. Activated carbon treatment, then I supplements
The assay organism was Gonyaulax tamarensis, Clone GT 429. Stock and assay cultures were judged to be axenic on the basis of microscope examination and sterility checks with tryptic soy broth medium. Culture incubation was at $18^{\circ} \mathrm{C} \pm 1 \mathrm{C}^{\circ}$ with $230 \mu \mathrm{E} \mathrm{m} \mathrm{m}^{-2} \mathrm{~s}^{-1}$ illumination from Westinghouse cool-white fluorescent lamps for 14 h a day. Stock cultures were maintained in F/2 medium (Guillard \& Ryther 1962) prepared with outer-shelf (Hudson Canyon) surface water. Assay inocula were grown for $28 \mathrm{~d}$ in $600 \mathrm{ml}$ of $\mathrm{F} / 100$ from a $10 \mathrm{ml}$ stock culture to nutrient-deplete the cells and minimize nutrient carry-over. Assay inoculation was by pipette. All the samples from a station were assayed as a set.

We employed an enrichment batch assay (Maestrini et al. 1984) in which experimental results are based on yield or maximum standing crop (MSC) (= algal growth potential). During incubation and especially just before counting the cultures were examined under the microscope for cell motility. Relatively long incubation terms ( 51 to $54 \mathrm{~d}$ ) were used in the assays because preliminary tests showed that this was necessary to ensure that all cultures reached MSC before being counted and to improve agreement among the 5 test replicates. The incubation terms included a lag phase of approximately $2 \mathrm{wk}$. Similar or longer lag phase following inoculation is common for the species (Prakash 1967, Cole et al. 1975, Yentsch et al. 1975). Regular culture optical density checks and microscope examination indicated that most assay cultures did not increase after $40 \mathrm{~d}$ and none decreased, observably, between Day 40 and the end of incubation. Cell concentration of the cultures was counted at the end of 
incubation with a Model ZB Coulter Counter. Differences in mean response to the various treatments were verified with the $t$-test and correlations were determined by the product-moment method. As used in this paper, the term 'growth' refers to increase of culture cell concentration over the inoculum level.

\section{RESULTS}

\section{Comparison of yield in unsupplemented water from both stations}

Throughout the assays, overall MSC in unsupplemented water from both locales was not significantly different (Table 2). However, the 4 highest doubling levels in unsupplemented water were in Station 13 samples. The 3 most extreme examples of culture inhibition were also in Station 13 samples (Aug6-B; Aug-20-S; Sep-2-S) as were the only 4 assays in which motile cells were not seen with microscope examination of the cultures at the end of incubation. The suitability for growth of Gonyaulax tamarensis in surface and bottom water of a particular date and station was similar in 2 instances (Stn 7, Sep-2-S,B; Sep-16-S,B) but was otherwise dissimilar. Highest doubling levels at Station 7 were in the July to early August samples but at Station 13 were in early August through September samples.

Table 2. Gonyaulax tamarensis. Growth in unsupplemented Lower New York Bay water samples and maximum growth in fully enriched and treated water in the particular assay; assays are designated by collection date and surface (S) or bottom (B). Data express the number of culture doublings from inoculum level over incubation term ( $\left.\operatorname{Stn} 7,54 \mathrm{~d}_{i} \operatorname{Stn} 13,51 \mathrm{~d}\right)$. $\mathrm{N}$ indicates no motile cells at end of incubation

\begin{tabular}{|c|c|c|c|c|c|}
\hline \multirow{2}{*}{$\begin{array}{l}\text { Datel } \\
\text { depth }\end{array}$} & \multicolumn{2}{|c|}{ Station 7} & \multicolumn{3}{|c|}{ Station 13} \\
\hline & $\begin{array}{l}\text { Unsup- } \\
\text { plemented, } \\
\text { untreated } \\
\text { water }\end{array}$ & $\begin{array}{l}\text { Fully } \\
\text { enriched, } \\
\text { treated } \\
\text { water }\end{array}$ & $\begin{array}{r}\text { Un } \\
\text { plem } \\
\text { untr } \\
\text { w }\end{array}$ & $\begin{array}{l}\text { nsup- } \\
\text { nented, } \\
\text { reated } \\
\text { rater }\end{array}$ & $\begin{array}{l}\text { Fully } \\
\text { enriched, } \\
\text { treated } \\
\text { water }\end{array}$ \\
\hline Ju] $08, \mathrm{~S}$ & 2.62 & 5.08 & & 1.01 & 4.97 \\
\hline Jul 08, B & 1.47 & 5.37 & $\mathrm{~N}$ & 1.33 & 4.01 \\
\hline Jul $26, \mathrm{~S}$ & 2.03 & 4.76 & & 1.96 & 5.89 \\
\hline Jul 26, B & 1.41 & 4.50 & & 1.10 & 5.48 \\
\hline Aug 06, S & 1.21 & 4.53 & & 3.79 & 6.05 \\
\hline Aug $06, B$ & 2.10 & 4.70 & & 0.43 & 4.36 \\
\hline Aug $20, \mathrm{~S}$ & 1.61 & 4.47 & $N$ & 0.34 & 5.47 \\
\hline Aug 20, B & 1.10 & 4.51 & & 1.06 & 4.34 \\
\hline Sep 02, S & 1.21. & 5.04 & $N-$ & -0.13 & 4.27 \\
\hline Sep 02, B & 1.06 & 4.78 & $N$ & 1.01 & 5.55 \\
\hline Sep $16, \mathrm{~S}$ & 1.41 & 4.57 & & 3.65 & 6.06 \\
\hline Sep $16, B$ & 1.48 & 4.93 & & 3.49 & 5.32 \\
\hline Sep $29, \mathrm{~S}$ & 1.02 & 5.45 & & 1.97 & 6.21 \\
\hline Sep 29, B & 1.34 & 4.67 & & 4.13 & 5.58 \\
\hline
\end{tabular}

Yield with various enrichments and treatments

Station 7

Single additions of nitrogen, phosphorus and vitamins mix were stimulatory in 9,5 , and 6 , respectively, of the 14 assays (Table $3 a$ ). MSC with nitrogen or phosphorus supplementation equalled or exceeded that of the other individual supplements in 4 assays. EDTA single supplementation improved yield in 1 assay. Metals mix was the most important single enrichment, being beneficial in 11 assays. In 5 of these, MSC associated with metals supplementation was significantly greater than that of the other supplements, when these were stimulatory; in 4 , metals mix was the only beneficial individual supplementation. With 2 exceptions, combination of metals and chelation was not advantageous and, in 5 assays, resulted in lower MSC than with metals alone. In combination with complete nutrient supplementation ( $N, P$, metals, vitamins), EDTA treatment increased MSC an average of $23 \%$ in 5 assays but was partially inhibitory in 2. Carbon treatment enhanced yield an average of $21 \%$ in 7 assays. In 5 assays, combined EDTA and carbon treatment provided the best water quality; in these, MSC was an average of $18 \%$ greater than with either treatment alone. The identification of trace metals as primary limiter is supported by an apparent necessity for metals enrichment as a prerequisite for utilization of ambient nitrogen. Ambient nitrogen levels (Table 4) correlate well with the MSC levels from single supplementation of the water with metals mix, whereas MSC in unsupplemented water and ambient nitrogen level are not related (Table 5).

\section{Station 13}

Single additions of nitrogen, phosphorus and vitamins mix improved yield in 5, 6, and 7 of the 14 assays, respectively (Table $3 \mathrm{~b}$ ). MSC levels provided by individual supplementation with nitrogen or phosphorus were equivalent with the levels associated with other individual supplements in 5 assays. Chelation with EDTA was favorable in 6 assays. Metals mix was the most important single supplement since it was beneficial in all but one assay. EDTA in combination with metals provided significantly greater yield than that with metals alone in 5 assays. The importance of chelation in this collection is evidenced also by the higher MSC with combined EDTA and complete nutrient supplementation (an average of $58 \%$ greater yield) in all but 3 of the assays. Carbon treatment significantly increased yield in 2 assays but reduced it in 9 others. Yield was maximum with combined chelation and carbon treatment in 1 sample; this combination was disad- 
Table 3. Gonyaulax tamarensis. Growth potential in Lower New York Bay water with various enrichments and treatments. Each line of data represents results from a separate assay, designated by sample collection date and depth (surface, S, or bottom, B). The data are, for the various ennichments and treatment, the percent of the highest yield in the particular assay. Underlining of data associated with individual enrichments (left section of table) indicates yield was significantly different $(p \geq 0.05)$ from that in the unsupplemented water; underline bridging adjacent data or, if data are not adjacent, the \# or \#\# symbol indicate statistically equivalent yields. Yields associated with complete nutrient supplementation and carbon, EDTA treatments (right section of table) are compared statistically as a group. Underlining (double) of data indicates significant difference $(p \geq 0.05)$ of yield from the maximum in the particular assay; continuous underlining or shared $\cdot$ symbol denotes statistical equivalence

(a) Station 7

\begin{tabular}{|c|c|c|c|c|c|c|c|c|c|c|c|}
\hline \multirow[t]{2}{*}{$\begin{array}{l}\text { Date/ } \\
\text { depth }\end{array}$} & \multirow{2}{*}{$\begin{array}{l}\text { No. nutrient } \\
\text { supplement } \\
\text { or treatment }\end{array}$} & \multicolumn{6}{|c|}{ Individual nutrient supplements } & \multicolumn{4}{|c|}{$\begin{array}{c}\text { Complete nutrient supplement (CNS) } \\
\text { plus indicated treatment }\end{array}$} \\
\hline & & $\mathrm{N}$ & $\mathrm{P}$ & Vit. & Met. & EDTA & $\begin{array}{l}\text { Met. }+ \\
\text { EDTA }\end{array}$ & $\begin{array}{l}\text { CNS } \\
\text { only }\end{array}$ & EDTA & Carbon & $\begin{array}{l}\text { EDTA + } \\
\text { Carbon }\end{array}$ \\
\hline Jul $08, \mathrm{~S}$ & 18.8 & 34.9 & $23.6^{*}$ & 17.6 & $24.3^{* 7}$ & 17.9 & 17.5 & 89.3 & 85.3 & 97.3 & 100.0 \\
\hline Jul $08, \mathrm{~B}$ & 6.6 & 13.2 & 7.2 & 7.7 & 7.0 & 6.6 & 6.8 & 74.4 & 76.4 & 77.2 & 100.0 \\
\hline Jul $26, \mathrm{~s}$ & 14.5 & $20.6^{\#}$ & 15.5 & 25.0 & $23.9^{*}$ & 14.1 & $25.0^{\#}$ & $\overline{100.0}$ & $\overline{94.4}$ & 95.8 & 94.2 \\
\hline Jul 26, B & 11.3 & $13.5^{*}$ & 11.4 & $14.1^{*}$ & 24.8 & 13.3 & 12.8 & 100.0 & $73.6^{\circ}$ & 96.7 & $79.5^{\circ}$ \\
\hline Aug $06, \mathrm{~S}$ & 9.8 & 9.6 & 9.9 & 10.2 & $\underline{32.2}$ & 11.4 & $\underline{26.0}$ & $74.0^{\circ}$ & 96.9 & $74.1^{\circ}$ & 100.0 \\
\hline Aug $06, \mathrm{~B}$ & 16.3 & 16.2 & 16.4 & 16.0 & 24.9 & 16.7 & $\underline{21.0}$ & $\underline{46.0}$ & 88.0 & 67.2 & 100.0 \\
\hline Aug $20, \mathrm{~S}$ & 13.6 & 15.4 & 16.9 & 13.0 & 50.4 & 13.0 & $\underline{43.5}$ & 85.5 & 95.2 & 98.4 & 100.0 \\
\hline Aug $20, B$ & 9.1 & 17.4 & $\underline{14.5}$ & 10.7 & $24.9^{\prime \prime}$ & 10.4 & $29.0^{* *}$ & $\overline{97.6}$ & 93.1 & 98.4 & 100.0 \\
\hline Sep 02, S & 7.2 & 7.3 & 7.6 & 7.6 & $25.5^{*}$ & 7.5 & $25.2^{*}$ & $61.7^{\circ}$ & 33.2 & 100.0 & $66.4^{\circ}$ \\
\hline Sep 02, B & 7.4 & 8.4 & 7.7 & 7.3 & 7.4 & 7.9 & $\underline{16.9}$ & 99.6 & 94.0 & 99.4 & 100.0 \\
\hline Sep 16, S & 11.2 & 21.3 & 22.4 & 21.4 & 28.1 & 9.6 & 29.6 & 100.0 & 99.5 & 98.8 & 95.1 \\
\hline Sep 16, B & 9.5 & $12.4^{*}$ & 9.8 & $11.2^{\#}$ & $31.5^{* * *}$ & 10.2 & $31.6^{* * *}$ & 69.1 & 87.2 & 88.6 & 100.0 \\
\hline Sep $29, \mathrm{~S}$ & 4.4 & 6.1 & 5.7 & $6.4^{\#}$ & $37.8^{* * *}$ & $6.2^{\#}$ & $32.6^{*}$ & 39.7 & 40.5 & 76.7 & 100.0 \\
\hline Sep 29, B & 10.0 & 19.0 & 18.2 & 10.0 & $53.0^{*}$ & 10.7 & $51.7^{\#}$ & 54.7 & $\underline{80.1}$ & 64.6 & 100.0 \\
\hline
\end{tabular}

(b) Station 13

\begin{tabular}{|c|c|c|c|c|c|c|c|c|c|c|c|}
\hline \multirow[t]{2}{*}{$\begin{array}{l}\text { Date/ } \\
\text { depth }\end{array}$} & \multirow{2}{*}{$\begin{array}{l}\text { No. nutrient } \\
\text { supplement } \\
\text { or treatment }\end{array}$} & \multicolumn{6}{|c|}{ Individual nutrient supplements } & \multicolumn{4}{|c|}{$\begin{array}{c}\text { Complete nutrient supplement (CNS) } \\
\text { plus indicated treatment }\end{array}$} \\
\hline & & $\mathrm{N}$ & $\mathrm{P}$ & Vit. & Met. & EDTA & $\begin{array}{l}\text { Met. }+ \\
\text { EDTA }\end{array}$ & $\begin{array}{l}\text { CNS } \\
\text { only }\end{array}$ & EDTA & Carbon & $\begin{array}{l}\text { EDTA + } \\
\text { Carbon }\end{array}$ \\
\hline Jul $08, \mathrm{~S}$ & 6.3 & 6.7 & 9.9 & 8.5 & 9.0 & 6.5 & 18.5 & $8.7^{\circ}$ & 100.0 & $9.3^{\circ}$ & 38.0 \\
\hline Jul $08, \mathrm{~B}$ & 16.3 & 15.1 & 18.3 & $\underline{20.0}$ & 16.2 & 15.6 & $\underline{76.1}$ & $53.0^{\circ}$ & 100.0 & $51.2^{\circ}$ & 70.7 \\
\hline Jul $26, \mathrm{~S}$ & 6.4 & 16.6 & $17.4^{*}$ & 6.3 & $\underline{17.4 *}$ & 6.7 & 12.2 & $21.5^{\circ}$ & 100.0 & 17.1 & $23.4^{\circ}$ \\
\hline Jul $26, \mathrm{~B}$ & 4.6 & 4.8 & 4.9 & 5.1 & $\underline{16.1^{*}}$ & $\underline{13.2}$ & $15.7^{*}$ & $\overline{35.6^{\circ}}$ & 100.0 & $34.1^{\circ}$ & $\overline{80.6}$ \\
\hline Aug 06, S & 21.3 & ${\underline{32.7^{\#}}}^{\#}$ & 20.9 & 20.9 & $\underline{29.7^{*}}$ & 19.9 & 21.3 & $\overline{100.0}$ & 94.4 & 61.7 & $\overline{75.5}$ \\
\hline Aug 06, B & 6.5 & 6.6 & 6.7 & 6.5 & 16.2 & 6.4 & 8.0 & 63.4 & 100.0 & 16.9 & 33.6 \\
\hline Aug $20, \mathrm{~S}$ & 2.8 & 3.4 & 3.6 & 4.1 & $\underline{17.8^{* *}}$ & 4.9 & $18.0^{\# *}$ & 4.9 & 100.0 & 7.6 & $\underline{26.8}$ \\
\hline Aug 20, B & 9.8 & 9.7 & 10.0 & 9.7 & $\underline{35.5^{* *}}$ & 10.0 & $\underline{33.2^{\#}}$ & 34.2 & 100.0 & 26.4 & 49.9 \\
\hline Sep 02, S & 4.3 & 6.3 & 4.9 & 7.2 & 7.1 & 7.3 & 3.6 & 7.8 & 5.5 & 52.7 & 100.0 \\
\hline Sep 02, B & 4.1 & 5.3 & $16.7^{*}$ & 6.9 & 7.3 & $19.9^{\# *}$ & 25.4 & $\overline{54.3}$ & $100 . \overline{0}$ & 1.8 & 1.7 \\
\hline Sep $16, S$ & 19.5 & $27.1^{\#}$ & 21.9 & 25.0 & $\underline{31.8^{\#}}$ & 22.7 & $\underline{31.8^{*}}$ & 58.5 & 100.0 & 10.6 & 18.8 \\
\hline Sep 16, B & 28.1 & 28.7 & 26.5 & 26.1 & 33.3 & 32.5 & 36.2 & 64.3 & 100.0 & 10.4 & 6.9 \\
\hline Sep $29, \mathrm{~S}$ & 5.1 & 6.4 & 5.4 & $6.5^{*}$ & 20.6 & $7.2^{*}$ & 33.4 & 64.6 & 100.0 & 10.6 & 12.8 \\
\hline Sep $29, B$ & 35.6 & 43.9 & $55.6^{*}$ & 34.1 & $54.2^{\#}$ & 38.8 & 71.7 & 99.0 & 100.0 & 43.3 & 81.2 \\
\hline
\end{tabular}


vantageous in the rest. As in the Station 7 assays, the need for metals mix supplementation as a prerequisite for utilization of ambient nitrogen (Table 4) supports the identification of trace metal as primary growth limiter. This is complicated in the surface water assays, however, by the apparent strong toxicity in the sample mentioned above and by a greater role for chelation.

Table 4. Levels of total inorganic nitrogen $\left(\mathrm{NH}_{4}, \mathrm{NO}_{2}, \mathrm{NO}_{3}\right)$ and phosphorus in assay samples before enrichment. Samples are designated by collection date and surface (S) or bottom (B)

\begin{tabular}{|c|c|c|c|c|}
\hline \multirow{2}{*}{$\begin{array}{l}\text { Date/ } \\
\text { Depth }\end{array}$} & \multicolumn{2}{|c|}{ Station 7} & \multicolumn{2}{|c|}{ Station 13} \\
\hline & $\begin{array}{c}\text { Total } \\
\text { inorganic } \\
\text { nitrogen } \\
\mu \mathrm{g} \text {-at } \mathrm{Nl}^{-1}\end{array}$ & $\begin{array}{l}\text { Reactive } \\
\text { phos- } \\
\text { phorus } \\
\mu g \text {-at } \mathrm{Pl}^{-1}\end{array}$ & $\begin{array}{c}\text { Total } \\
\text { inorganic } \\
\text { nitrogen } \\
\text { ug-at } \mathrm{Nl}^{-1}\end{array}$ & $\begin{array}{l}\text { Reactive } \\
\text { phos- } \\
\text { phorus } \\
\mu g \text {-at } \mathrm{Pl}^{-1}\end{array}$ \\
\hline Jul $08, \mathrm{~S}$ & 20.23 & 1.48 & 11.23 & 1.15 \\
\hline Jul $08, B$ & 15.83 & 1.07 & 8.28 & 1.42 \\
\hline Jul $26, \mathrm{~S}$ & 25.84 & 1.72 & 18.41 & 2.06 \\
\hline Jul 26, B & 22.71 & 1.53 & 13.07 & 2.11 \\
\hline Aug 06, S & 28.03 & 2.09 & 20.28 & 1.80 \\
\hline Aug $06, \mathrm{~B}$ & 22.54 & 1.53 & 14.07 & 1.56 \\
\hline Aug $20, \mathrm{~S}$ & 42.08 & 2.37 & 20.71 & 1.53 \\
\hline Aug $20, B$ & 18.37 & 1.94 & 19.25 & 1.27 \\
\hline Sep 02, S & 27.56 & 1.07 & 24.61 & 0.43 \\
\hline Sep 02, B & 18.12 & 0.76 & 20.73 & 0.49 \\
\hline Sep 16, S & 42.64 & 1.83 & 26.63 & 1.06 \\
\hline Sep 16, B & 35.81 & 2.05 & 27.87 & 0.84 \\
\hline Sep 29, S & 62.41 & 1.42 & 48.05 & 1.25 \\
\hline Sep 29, B & 62.37 & 1.53 & 47.08 & 1.26 \\
\hline
\end{tabular}

Table 5. Gonyaulax tamarensis. Correlation coefficients $(r)$ for assays in Lower New York Bay water

Correlation of yield in variously $\quad t$

treated water with ambient

nitrogen level $(\mathrm{N})$

\section{Station 7}

Unsupplemented water (USW), $\quad-0.60$

surface $(S): N, S$

USW, bottom (B) : N, B

Metals mix supplementation,

$S: N, S$

Metals mix supplementation,

$B: N, B$

\section{Station 13}

Metals mix supplementation,

$S: N, S$

Metals mix plus EDTA, $S: N, S$

Above, minus $\mathrm{MSC}$ value from

toxic sample: $N, S$

USW, B:N, B

Yield, Station 7 : Yield, Station 13

USW, S: USW :

USW, B: USW, B

Fully supplemented water

(FSW), S: FSW, S

FSW, B:FSW, B
Metals mix stimulated higher MSC in all surface samples except the strongly inhibitory one. However, significant correlation with ambient nitrogen (Table 5) required a combination of metals and chelation and deletion of the data from the strongly inhibitory sample assay. In the bottom samples, there is a clear relationship between MSC in the unsupplemented water and ambient nitrogen level (Table 5).

\section{DISCUSSION}

We assume that the responses of the well-studied and representative Gonyaulax tamarensis Clone 429 in our assays are generally attributable to the species. Our results suggest a complex relationship between $G$. tamarensis growth and chemical water quality in Lower New York Bay. This species, for the most part, likely would not be controlled by nitrogen availability. Nitrogen had primary importance in growth limitation, or shared primary importance with one or more other enrichments, in just 7 and $18 \%$ of the assays, respectively. Phosphorus only had shared primary limitation importance in $18 \%$ of the assays. Vitamins had primary importance in 1 assay and shared primary importance in $14 \%$ of the assays. There was limited correlation of assay yield with ambient levels of nitrogen and none with ambient phosphorus. This relative unimportance of nutrient limitation is not unexpected since Draxler et al. (1984) found lowered nitrogen levels associated with an August phytoflagellate bloom in part of the Hudson-Raritan estuary but otherwise consistently high nitrogen and phosphorus levels in this estuary during spring and summer.

Metal supplementation (one or more essential metals in the enrichment mixture) did far more to relieve growth limitation in the assays than nitrogen, phosphorus or vitamins. Apparently, the latter nutrients and growth factors were usually in high enough levels to defer limitation to required metals; the role of anthropogenic inputs in promoting this type of situation in some coastal waters was suggested by Dunstan (1975).

Because the chemical water quality of the lower Hudson-Raritan estuary is strongly influenced by anthropogenic inputs, especially metals and hydrocarbons (Breteler et al. 1984, Neff 1984, Zitko \& Boehm 1984), the assays emphasized the possible effects of these classes of pollutants on growth of Gonyaulax tamarensis. Chelation may make weakly soluble metals available to phytoplankton (Johnston 1964) but, potentially more important in Lower New York Bay, it can ameliorate the detrimental effects of metals such as copper whose toxicity is related to free ion activity (Steemann Nielsen \& Wium-Anderson 1970, Sunda \& Guillard 1976). Activated carbon is commonly used to 
remove organic compounds from water and has been so employed in a marine phytoplankton enrichment study (Barber et al. 1971); according to these authors, carbon removes certain types of organic compounds from sea water but does not remove nitrite, nitrate or phosphate. Activated carbon can also absorb metals including copper, lead and cobalt (Netzer \& Hughes 1984) and arsenic (Huang \& Fu 1984).

Metal toxicity was common in water from Station 13, judging by the repeated benefit to growth from chelation with EDTA. The lessening of inhibition in some samples from both stations, by treatment of the water with activated carbon, suggests the presence of toxic organic compounds or, possibly, metal toxicity not relieved by chelation. Finally, equivalent benefit to Gonyaulax tamarensis growth by phosphorus, nitrogen and EDTA in 2 samples (see Station 13 data) was possibly related to metal toxicity. Nitrogen concentration was especially high in 1 of the 2 and the toxicity of certain metals to phytoplankton species can be mediated by the levels of nitrogen ( $\mathrm{Li}$ 1978) and phosphorus (Sicko-Goad \& Stoermer 1979). Only the growth inhibition that persisted to the end of long incubation was detected by the assays; lesser effects such as temporary reductions in growth rate may also have occurred but were not examined.

The northern station (7) and southern station (13) represent regions of the bay strongly influenced by Hudson River and Raritan River flow, respectively (Draxler et al. 1984). Therefore, some water quality differences are to be expected and were evident. Temporal difference in greatest suitability of the water from the 2 stations has already been pointed out. Assay responses in water from the 2 stations throughout the study were not correlated (Table 5). Nitrogen limited more frequently in the southern station samples; there was also a direct relationship between assay growth and inorganic nitrogen levels in the bottom water although this was not evident in the surface samples. The other nutrients examined had approximately equal importance for both stations. Major differences between the 2 stations related to chelation and activated carbon treatment. In the Station 7 assays, EDTA added singly increased growth in just 1 sample and when added with the complete nutrient supplement was beneficial in just 5 , and detrimental in 2 . Carbon treatment enhanced growth in approximately one third of the samples and was never detrimental. In contrast, EDTA was very beneficial in the Station 13 samples and carbon treatment was detrimental in all but 1 assay. This suggest that the unfavorable water quality detected in samples from the 2 stations was due to different types of growth inhibitor.

Information on water suitability for Gonyaulax tamarensis derived from 1 season and 2 sites may not support high predictive capability about potential growth of the species in the lower Hudson-Raritan estuary. However, this system has been seriously polluted with domestic and industrial wastes for many years without wide major abatement and this consistency lends support to some general conclusions. It is not likely that $G$. tamarensis would be nutrient limited in New York Harbor. However, the often unfavorable chemical water quality indicated by this study, assuming it persists in importance from year-to-year, suggests that this can be an important regulator and that, in consequence, the lower estuary would not be a generally favorable habitat for the species

The assay results also suggest, nevertheless, that the bay water quality will not exclude the species and at times and places may be suitable. In those samples apparently having the least favorable water quality, untreated and unsupplemented assay water (except for an undetermined, relatively small amount of nutrient carry-over from the inoculum) was growth inhibitory but the inoculum was not always killed. Some growthfavorable samples supported 3 to 4 doublings of the inoculum without enrichment (Table 2), which is considerable for this species and the culture method employed. In summary, our results suggest that Gonyaulax tamarensis may be able to flourish in at least part of the bay when the chemical water quality is temporarily favorable for its growth but it is unlikely to become a principal resident species.

Acknowledgements. The authors thank K. McNulty for advice and help on statistical treatment of data. J. McGhee, D. Johnson and K. Manigrasso provided technical assistance during various parts of the study. The figure was drawn by M. Cox, and A. Gruber did the word processing. We thank the Center for Culture of Marine Phytoplankton, Bigelow Laboratory, West Boothbay Harbor, Maine for providing a culture of Gonyaulax tamarensis.

\section{LITERATURE CITED}

Anderson, D. M., Kulis, D. M., Orphanos, J. A., Ceurvels, A. R. (1982). Distribution of the toxic dinoflagellate Gonyaulax tamarensis in the southern New England region. Estuar. coast. Shelf Sci. 14: 447-458

Anderson, D. M., Morel, F. M. M. (1978). Copper sensitivity of Gonyaulax tamarensis. Limnol. Oceanogr. 23: 283-295

Biggs, D. C., Rowland, R. G., O'Connors, Jr, Powers, C. D., Wurster, C. F. (1978). A comparison of the effects of chlordane and PCB on the growth, photosynthesis, and cell size of estuarine phytoplankton. Environ. Pollut. 15: 253-263

Barber, R. T., Dugdale, R. C., Macisaac, J. J., Smith, R. L. (1971). Variations in phytoplankton growth associated with the source and conditioning of upwelling water Invest. Pesq. 35: 171-193

Breteler, R. J., Rachlin, J. W., Engle, D. W. (1984). Metals subpanel report. In: Breteler, R. J. (ed.) Chemical pollution of the Hudson-Raritan estuary. NOAA Technical Memorandum NOS OMA 7. Rockville, Maryland, p. 12-35 Carlucci, A. F. (1973). Bioassay: Biotin. In: Stein, J. R. (ed.) 
Handbook of phycological methods, culture methods and growth measurements. Cambridge University Press, Cambridge, p. 377-385

Cohn, M. S., Olsen, P., Mahoney, J. B., Feerst, E. (1988). Occurrence of the dinoflagellate Gonyaulax tamarensis in New Jersey. Bull. N. J. Acad. Sci. (in press)

Cole, E. J., Yentsch, C. M., Yentsch, C. S., Salvaggio, M. (1975). Some of the growth characteristics of Gonyaulax tamarensis isolated from the Gulf of Maine. Environ. Lett. 9: 153-166

Draxler, A. F. J., Waldhauer, R., Matte, A., Mahoney, J. B. (1984). Nutrients, hydrography, and their relationship to phytoflagellates in the Hudson-Raritan estuary. Bull. N. J. Acad. Sci. 29: 97-120

Dunstan, W. M. (1975). Problems of measuring and predicting influence of effluents on marine phytoplankton. Environ. Sci. Technol. 9: 635-638

Federal Water Pollution Control Administration, U. S. Dept of the Interior, New York (1967). Conference on pollution of Raritan Bay and adjacent interstate waters. Third Session. Proceedings, Vol. 1

Fisher, N. S., Carpenter, E. J., Remsen, C. C., Wurster, C. F (1974). Effects of PCB on interspecific competition in natural and gnotobiotic phyloplankton communities in continuous and batch cultures. Microb. Ecol. 1: 39-50

Guillard, R. R. L., Ryther, J. H. (1962). Studies of marine planktonic diatoms. 1. Cyclotella nana Hustedt, and Detonula confervacea (Cleve). Can. J. Microbiol. 8: 229-239

Huang, C. P., Fu, P. L. K. (1984), Treatment of arsenic (V)containing water by the activated carbon process. $J$. Wat. Poll. Control Fed. 56: 233-242

Johnston, R. (1964). Sea water, the natural medium of phytoplankton. II. Trace metals and chelation and general discussion. J. mar. biol. Ass. U. K. 44: 87-107

Liddicoat, M. J., Tibbits, S., Butler, E. I. (1975). The determination of anmonia in sea water. Limnol. Oceanogr. 20: 131-132

Li, W K. W. (1978). Kinetic analysis of interactive effects of cadmium and nitrate on growth of Thalassiosira fluviatilis (Bacillariophyceae). J. Phycol. 14: 454-460

Maestrini, S. Y., Bonin, D. J., Droop, M. R. (1984). Phytoplankton as indicators of sea water quality: bioassay approaches and protocols. In: Shubert, L. E. (ed.) Algae as ecological indicators. Academic Press, London, p. 71-132

Mahoney, J. B., McLaughlin, J. J. A. (1977). The association of phytoflagellate blooms in Lower New York Bay with hypertrophication. J. exp. mar. Biol. Ecol. 28: 53-65

Maranda, L., Anderson, D. M., Shimizu, Y (1985). Comparison of toxicity between populations of Gonyaulax tamarensis of Eastern North American waters. Estuar coast. Shelf Sci. 21: 401-410

Marshall, H. G., Cohn, M. S. (1981). Phytoplankton community structure in northeastern coastal waters of the United States. 1. October 1978. NOAA Tech. Memo. NMFS-F/ NEC-8. Woods Hole, Massachusetts, p. 1-57

Mueller, J. A., Jeris, J. S., Anderson, A. R., Hughes, C. (1976). Contaminant inputs to the New York Bight. NOAA Tech. Memo. ERL MESA-6, Mar Eco. Syst. Anal. Prog. Office, Boulder, Colorado, p. 1-347

Murphy, J., Riley, J. P. (1962). A modified single solution method for the determination of phosphate in natural waters. Analytica chim. Acta $27: 31-36$

Neff, J. M. (1984). Petroleum hydrocarbons subpanel report. In: Breteler, R. J. (ed.) Chemical pollution of the HudsonRaritan estuary. NOAA Technical Memorandum NOS OMA 7, Rockville, Maryland, p. 36-46

Netzer, A., Hughes, D. E. (1984). Adsorption of copper, lead and cobalt by activated carbon. Wat. Res. 8: 927-933

Olsen, P., Cohn, M. (1979). Phytoplankton in Lower New York Bay and adjacent New Jersey estuarine and coastal areas. Bull. N. J. Acad. Sci. 24: 59-70

Olsen, P. (1983). Summary of phytoplankton dynamics and bloom incidence in New Jersey coastal waters. Report, New Jersey Dept. of Environmental Protection, Division of Water Resources, Trenton, New Jersey, p. 1-12

O'Reilly, J., Thomas, J. P., Evans, C. (1976). Annual primary production (nanoplankton, netplankton, dissolved organic matter) in the Lower New York Bay. In: McKeon, W H., Lauer, G. J. (eds.) Proc. 4th symp. Hudson River ecology. Hudson River Environmental Society, Inc., New York, p. $1-39$

Prakash. A. (1967). Growth and toxicity of a marine dinoflagellate, Gonyaulax tamarensis. J. Fish. Res. Bd Can. 24: $1589-1.606$

Prager, J. C., Mahoney, J. B., McLaughlin, J. J. A. (1963). Isolation and culture of luminescent Gonyaulax scrippsae. J. Protozool. 10 (Suppl.): 10

Schenck, R. C. (1984). Copper deficiency and toxicity in Gonyaulax tamarensis (Lebour). Mar. Biol. Lett. 5: 13-19

Schrey, S. E., Carpenter, E. J., Anderson, D. M. (1984). The abundance and distribution of the toxic dinoflagellate, Gonyaulax tamarensis, in Long Island estuaries. Estuaries 7. $472-477$

Segar, D. A., Cantillo, A. Y. (1976). Trace metals in the New York Bight. Am. Soc. Kimnol. Oceanogr. Spec. Symp. 2: 171-198

Sicko-Goad, L., Stoermer, E. F. (1979). A morphometric study of lead and copper effects on Diatoma tenue var. elongatum (Bacillariophyta). J. Phycol. 15: 316-331

Steemann Nielsen, E., Wium-Anderson, S. (1970). Copper ions as poison in the sea and in freshwater. Mar. Biol. 6: 93-97

Sunda, W. G., Guillard, R. R. L. (1976). Relationship between cupric ion activity and the toxicity of copper to phytoplankton. J. mar Res. 34: 511-529

U. S. Geological Survey (1983a). Water resources data, New York, water year 1982. Water Data Report NY 82-1. Vol. 1. U. S. Geological Survey, Albany, New York, p. 1-267

U. S. Geological Survey (1983b). Water resources data, New Jersey, water year 1982. Water Data Report NJ 82-1 Vol. 1. U. S. Geological Survey, Trenton, New Jersey, p. 1-329

Waldhauer, R. A., Matte, A., Tucker, R. (1978). Lead and copper in the waters of Raritan and Lower New York Bays. Mar. Pollut. Bull. 9: 37-42

Wood, E. D., Armstrong, F. A. J., Richards, F. A. (1964) Determination of nitrate in sea water by cadmium-copper reduction to nitrite. J. mar biol. Ass. U. K. 47: 23-31

Yentsch, C. M., Cole, E. J., Salvaggio, M. G. (1975). Some of the growth characteristics of Gonyaulax tamarensis isolated from the Gulf of Maine. In: LoCicero, V R. (ed.) Proceedings of the first international conference on toxic dinoflagellate blooms. Mass. Sci. Technol. Foundn., Wakefield, Massachusetts, p. 163-180

Zdanowicz, V S., Gadbois, D. F.. Newman, M. W (1986) Levels of organic and inorganic contaminants in sediments and fish tissues and prevalences of pathological disorders in winter flounder from estuaries of the Northeast United States, 1984 IEEE Oceans '86 Conference Proceedings. The Institute of Electrical and Electronics Engineers, Inc. New York, p. 578-585

Zitko, V., Boehm, P. D. (1984). Halogenated hydrocarbons subpanel report. In. Breteler, R. J. (ed.) Chemical pollution of the Hudson-Raritan estuary. NOAA Technical Memorandum NOS OMA 7. Rockville, Maryland, p. 47-61 